\title{
FRAGMENTA PALYNOLOGICA
}

(11)

\section{PALYNOLOGICAL STUDY OF ENDEMIC TAXA FROM SICILY AND CENTRAL-SOUTHERN ITALY.}

Walter DE LEONARDIS \& Antonina ZIZZA

Key words. Palynology, endemisms, Sicily, Central-Southern Italy.

Parole chiave: Palinologia, endemismi, Sicilia, Italia Centro Meridionale.

This survey of the pollen morphobiometry of twenty-two endemic taxa from Sicily and Central-Southern Italy provides a further contribution to the knowledge of the Sicilian pollen flora (Accorsi et al. 1984; De Leonardis et al. 1984a, 1986a, 1989a).

Pollen was acetolysed according to Erdtman (1960). The measurements by light microscope were made using a Zeiss compound microscope with $100 x$ (N.A.1,30) in oil immersion and $10 \mathrm{x}$ eyepieces. For the observations of the sporodermic wall by scanning electron microscope (JSM 35) polliniferous material was acetolysed, washed, progressively dehydrated by alcohol, dried by critical point and coated with gold $(100 \AA)$.

The terminology adopted was that of Wodehouse (1932), Erdtman (1969), Faegri \& Iversen (1975), Punt (1984), De Leonardis et al. (1986b).

The polliniferous material was collected from wild taxa and from herbarium specimens. The specimens are deposited in the Catania herbarium (CAT).
The morphobiometry of twenty-two taxa is reported in table 1 .

\section{RESULTS AND DISCUSSION}

\section{Berberis aetnensis C. Presl}

Pollen is characterized by apolar and bilateral monads with colpate apertures whose number varies and by irregular or spiralate arrangement $(\mathrm{NPC}=803)$. The exine is of uniform thickness and is tectate psilate with rare perforations. The size of grains confirms data reported by Fernández (1987a) for $B$. hispanica Boiss. \& Reuter and by Nowicke \& Skvarla (1981) for several Berberis species, (fig. 1: 1).

\section{Betula aetnensis Rafin.}

The polar outline of this species is goniotreme. Apertures are porate (lalongate $20 \%$, lolongate $70 \%$ and circular $10 \%$ ) with aspis (sensu Wodehouse 1932). The shape of grains is oblate $(25 \%)$, suboblate $(70 \%)$ and oblate spheroidal (5\%). Exine ornamentation 
is of the Betula type described by Lieux (1980). Grain size $(\mathrm{PxE}=18-25 \times 26-30 \mu \mathrm{m})$ confirms data reported by Takeoka \& Stix (1963), Birks (1969) and Nilsson et al. (1977) for several species belonging to the genus Betula, (fig. 1:2-3).

Erysimum metlesicsii Polatschek;

Arabis rosea DC.

These species are reticulum finely reticulate at the poles and medium-reticulate at the equator. The shape of grains is oblate spheroidal $(47 \%)$, spherical $(33 \%)$, prolate spheroidal $(20 \%)$ in E. metlesicsii whereas in A. rosea grains are spherical $(20 \%)$, prolate spheroidal (67\%) and subprolate (13\%). Both species are characterized by pollens which have 3 longitudinal colpi with regular edges. Grains of E. metlesicsii are distinguished from E. cheiri (L.) Crantz for the $2(5 \%), 3(90 \%)$ and $4(5 \%)$ colpi with irregular edges (De Leonardis et al. 1982) present in the latter species, (fig. 1: 4-5).

Erucastrum virgatum (J. \& C. Presl) C. Presl Pollen falls within the subtypes equatorial reticulate eu-reticulate and polar finely reticulate medium-reticulate. Grains are spheroidal (93\%) and prolate spheroidal (7\%) with 3 fusiform colpi, (fig. 1: 6).

\section{Matthiola incana (L.) R. Br. ssp. rupestris (Rafin.) Nyman;}

\section{M. fruticulosa (L.) Maire}

Both taxa have 3 colpi often difficult to distinguish by LM due to the fragility of the sporodermic wall and the very wide lumina (eu-reticulate and hyper-reticulate types). As a result, when the acute apices of the colpi are just visible in polar view (M. fruticulosa) the polar outline is ptycotreme subtriangular whereas when the apex colpi are not visible at the poles ( $M$. incana ssp. rupestris) the polar outline is subcircular, (fig. 2: 1-4).

Euphorbia amygdaloides L. ssp. arbuscula Meusel;

\section{E. ceratocarpa Ten.; \\ E. gasparrinii Boiss. ssp. gasparrinii; \\ E. corallioides L.}

The four taxa examined show evident morphological uniformity. The 3 colpi have parallel edges which meet in the median zone due to the presence of two exine expansions (becs sensu Bonnefille 1971) which conceal the ora. Costae and psilate margo are present (fig. 2: 5). The size of grains distinguishes $E$. amygdaloides ssp. arbuscula $(\mathrm{P}=32-38 \mu \mathrm{m})$ from E. ceratocarpa, E. gasparrinii ssp. gasparrinii and $E$. corallioides $(\mathrm{P}=39-54 \mu \mathrm{m})$. The observations with scanning electron microscope of the sporodermic wall in the four taxa illustrate sexine ornamentation formed by funnel-shaped cavities which have perforate base. Ferguson \& Strachan (1982) observe a very similar pattern in the Indigoforeae (Leguminosae) which they define as «pittedperforate». Examination of sections of the sporoderm shows, from the outside to the inside, three layers: partial tectum having infratectate cavities with perforate base; infratectate columellar layer with columellae which are distally fused; nexine, (fig. 2: 5-6 and fig. 3: 1-2).

Acinos granatensis (Boiss. ex Reuter) Pignatti ssp. aetnensis (Strobl) Pignatti

The pollen of this taxon have 6 longitudinal fusiform colpi. Shape is suboblate (43\%) and oblate spheroidal (57\%). Exine thickness $(1,73 \mu \mathrm{m})$ is uniform at equator and poles. Ornamentation is finely reticulate with lumina $<0,50 \mu \mathrm{m}$. Our data are in agreement with the values reported by Luque \& Candau (1987) for A. alpinus (L.) Moench ssp. meridionalis (Nyman) P.W. Ball, (fig. 3: 3-4).

\section{Astragalus nebrodensis (Guss.) Strobl}

The pollen grains have medium-small size $(\mathrm{P}=24-29 \mu \mathrm{m})$. The shape is subprolate $(80 \%)$ and prolate $(20 \%)$. Apertures have 3 longitudinal colpi each equipped with os. 

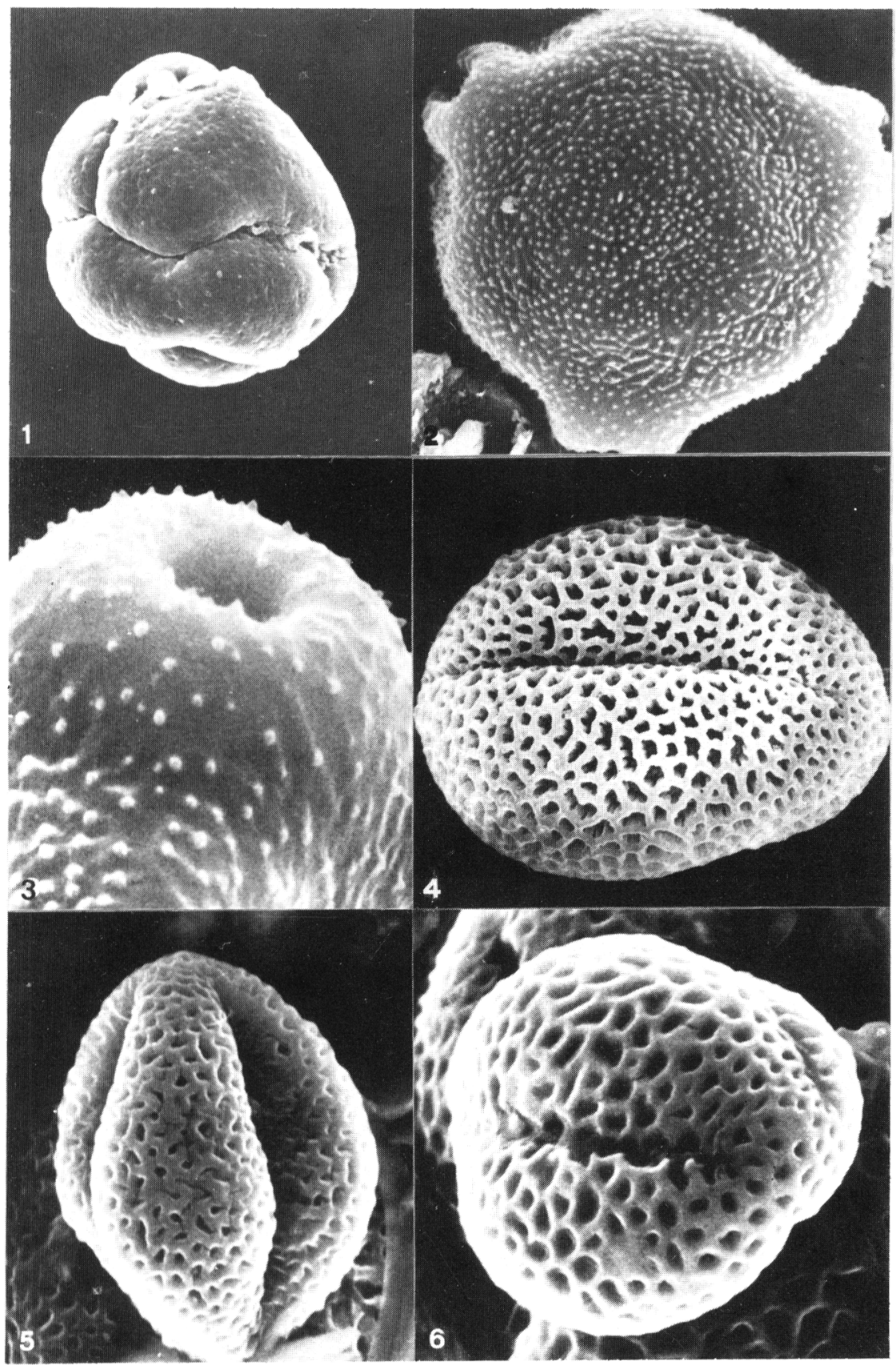

Figure 1: 1, Berberis aetnensis: apolar grain with spiralate colpi (1,500x). 2, Betula aetnensis, polar view (3,000x). 3, B. aetnensis, poral aperture with microspinulate exine $(10,000 \mathrm{x}) .4$, Erysimum metlesicsii, equatorial view with colpus $(4,000 \mathrm{x}) .5$, Arabis rosea, equatorial view with medium reticulate mesocolpium $(4,000 x) .6$, Erucastrum virgatum, equatorial and polar views $(4,400 x)$. 


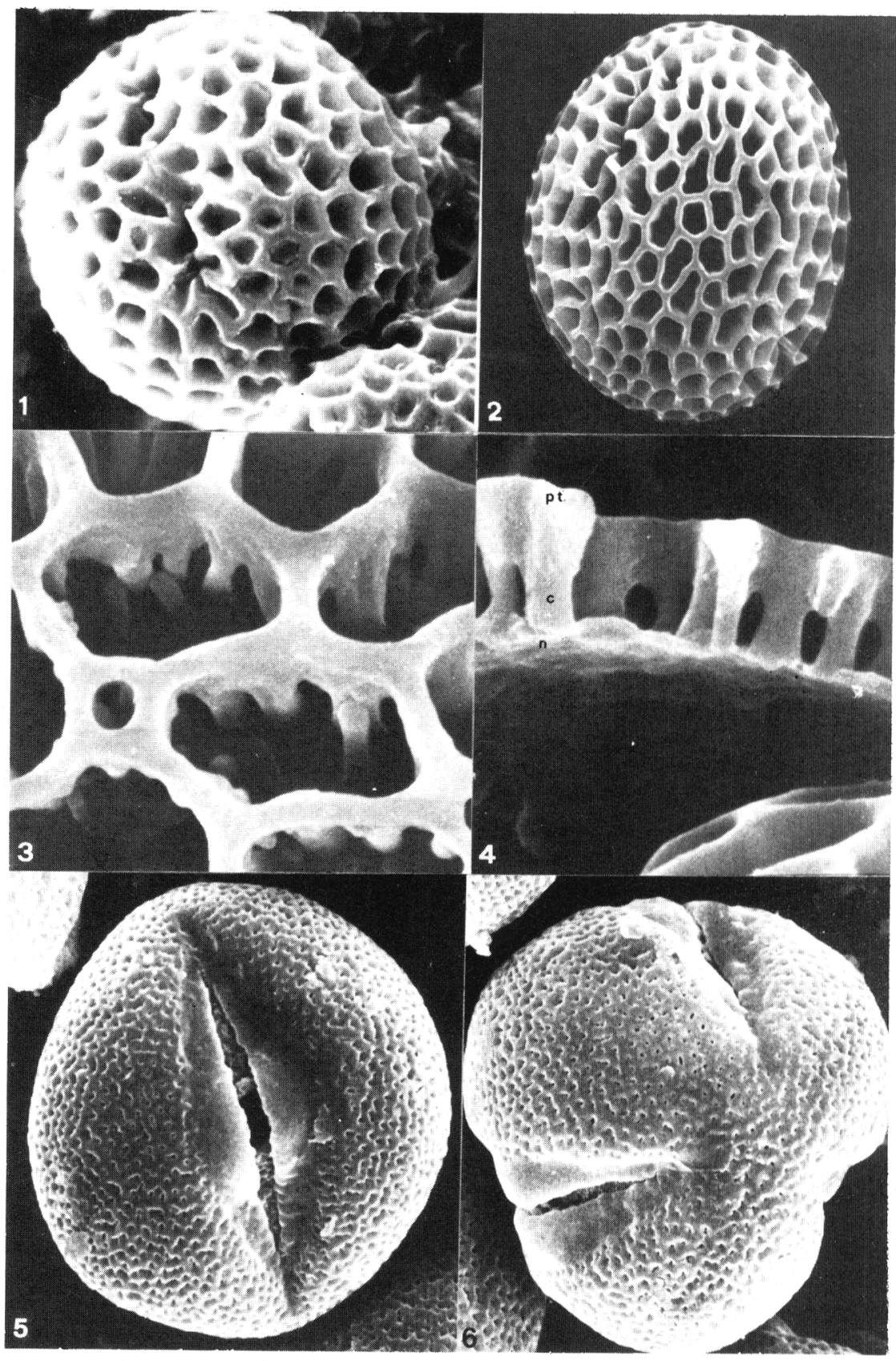

Figure 2: 1, Matthiola incana ssp. rupestris: equatorial view with colpus (3,000x). 2, M. fruticulosa, equatorial view with mesocolpium (3,000x). 3, M. fruticulosa, hyper-reticulate reticulum $(10,000 \mathrm{x}) .4, M$. fruticulosa, exine section with nexine (n), columellae (c) and partial tectum (pt) $(9,400 \mathrm{x})$. 5, Euphorbia amygdaloides ssp. arbuscula, equatorial view with colporate aperture $(2,400 \mathrm{x}) .6, E$. ceratocarpa, polar view $(2,600 x)$. 
Nexine thickening (costae) occurs near to the endoaperture while sexine thickening (margo sensu Moore \& Webb 1978) is present along colpus edges. Ornamentation is finely reticulate $(<0,50 \mu \mathrm{m})$ and consists of psilate muri which surround lumina whose diameter is greater than the thickness of the muri. The lumina have the form of small funnel-shaped cavities with perforate base.

The grains of $A$. nebrodensis are distinguished by $A$. siculus $\mathrm{Biv}$. $(\mathrm{P}=26-33 \mu \mathrm{m})$ in De Leonardis et al. (1986a) and by $A$. boeticus L., A. echinatus Murray, A. hamosus L. $(\mathrm{P}=31-34 \mu \mathrm{m})$ and A. lusitanicus Lam $(\mathrm{P}=18$ $22 \mu \mathrm{m}$ ) in Fernández (1987b), (fig. 3: 5-6).

\section{Cytisus aeolicus Guss.}

Grain size $(P=19-23 \mu \mathrm{m})$ distinguishes this taxon from $C$. moleroi Fdez. Casas $(\mathrm{P}=14$ $19 \mu \mathrm{m})$ in Trigo et al. (1991), C. arboreus (Desf.) DC. ssp. malacitanus (Boiss.) Malagarriga $(\mathrm{P}=25-29 \mu \mathrm{m})$ in Bootello et al. (1989), C. scoparius (L.) Link. and C. striatus (Hill) Rothm $(\mathrm{P}=24-33 \mu \mathrm{m})$ in Fernández (1987b). However, some biometric overlapping ( $\mathrm{P}=20-31 \mu \mathrm{m}$ ) occurs with $C$. baeticus (Webb) Steudel, C. fontanesii Spach ex Ball and C. grandiflorus DC. (Fernández 1987b).

The shape of grains is oblate spheroidal $(33 \%)$, spherical $(20 \%)$ and prolate spheroidal (47\%). The colpi, lacking margo, have parallel edges and lolongate ora (trizonocolporate). Exine ornamentation is finely reticulate with irregular muri and with funnel-shaped cavities which have perforate base. Fernández (1987b), Bootello et al. (1989) and Trigo et al. (1991) observe a verruca - or small granulum - like protuberance at the base of each lumen. In $C$. aeolicus we interpret this process as the caput of a columella of the infratectate layer which sometimes protrudes through the basal perforation in the cavity, (fig. 4: 1-2).

\section{Lathyrus odoratus L.}

Pollen grains are characterized by prolate shape $(100 \%)$ and medium-large size $(\mathrm{P}=42$ $52 \mu \mathrm{m})$. The apertures are formed by narrow colpi with acute apices and lalongate ora. Presence of margo and costae. The exine is tectate suprareticulate with luminoid depressions of the hyper-reticulate type $(>2,0$ $\mu \mathrm{m})$. The size of lumina is greater than data reported by Fernández (1987b) for nine Lathyrus species included in the Trifolium arvense type, (fig. 4: 3-4).

\section{Retama raetam (Forsskàl) Webb ssp. gussonei} (Webb) Greuter

Pollen grains are medium-small size $(\mathrm{P}=21-30 \mu \mathrm{m})$. Shape is suboblate $(3 \%)$, oblate spheroidal $(37 \%)$, spherical $(17 \%)$, prolate spheroidal $(23 \%)$, subprolate $(7 \%)$ and prolate (10\%). The colpi, equipped with margo, can have parallel edges and visible lolongate ora (50\% trizonocolporate) or edges which meet in the median zone and conceal the ora $(50 \%$ trizonocolporoidate). Exine ornamentation of the mesocolpium and apocolpium is medium reticulate.

Both biometric and morphological data support observations by Fernández (1987b) for $R$. monosperma (L.) Boiss. and $R$. sphaerocarpa (L.) Boiss. included in the Cytisus scoparius type, (fig. 4: 5-6)

\section{Verbascum rotundifolium Ten. ssp. rotundifolium}

Pollen grains have 3 colpi with parallel edges and lalongate (7\%) or lolongate $(93 \%)$ ora. The shape is suboblate $(13 \%)$ and oblate spheroidal $(87 \%)$. Sexine ornamentation is medium reticulate in agreement with Godoy \& Diez (1987) who place in the $V$. pulverulentum type $V$. rotundifolium Ten. $V$. pulverulentum Vill., V. simplex Hoffmanns., V. sinuatum L., V. virgatum Stokes, (fig. 5: 1-2).

Odontites bocconei (Guss.) Walpers

The morphological features of this species permitted the definition of a fourth pollen type 
with respect to the three types reported by Inceoglu (1982) for taxa of the genus Odontites. We describe the mesocolpium as having reticulum from finely reticulate to medium reticulate and lumina which become progressively wider in the apocolpia. Apertures are formed by 3 fusiform colpi equipped with membrane. Shape is suboblate $(27 \%)$, oblate spheroidal (60\%) and spherical (13\%). The size of grains $(\mathrm{P}=19-24 \mu \mathrm{m})$ is an additional distinguishing character as compared to the taxa examined by Inceoglu (1982), (fig. 5: 34).

\section{Celtis aetnensis Strobl}

The pollen exhibit distinct dimorphism in both the size of grains and the distribution of poral apertures. Grains can have annulate or operculate pores located in the equatorial zone (3-zonoporate $44 \%$ and 4-zonoporate $56 \%$ ) in which $\mathrm{P}=21-30 \mu \mathrm{m}$ or they can have 4-6 pores uniformly distributed over the surface of the polypantoporate grains with $\mathrm{DM}=31-46 \mu \mathrm{m}$. Both morphotypes present 2-3 additional small pores, randomly scattered over the grain surface, which frequently converge. The shape of polar grains is suboblate $(80 \%)$ and oblate spheroidal $(20 \%)$ while apolar grains are spherical $^{\circ}(10 \%)$, prolate spheroidal ${ }^{\circ}(80 \%)$ and subprolate $^{\circ}(10 \%)$. Exine is tectate microspinulate and slightly undulate. The size of grains confirms measurements reported by Bonnefille (1971) for C. kraussiana Bernh., by Lieux (1980) for C. laevigata Willd. and by Diez (1987) for $C$. australis, (fig. 5: 5-6).

\section{Seseli bocconi Guss. ssp. bocconi}

The pollen grains are characterized by slight columellar hypertrophy in the equatorial zone. It may sometimes be absent. The polar outline ranges from pleurotreme subtriangular with protruding apices to pleurotreme subtriangular with non-protruding apices (lobate outline). The 3 colpi are short and narrow, ora are lalongate. The shape of grains is always subrectangular and exine is rugulate. Grain size $(\mathrm{P}=22-28 \mu \mathrm{m})$ confirms data reported by Pardo (1982) for several taxa of the genus Seseli L. (fig. 6: 1-2).

\section{Bonannia graeca (L.) Halacsy}

Hypertrophy is absent. The polar outline is pleurotreme subtriangular with nonprotruding apices. Shape is subrectangular. The apertures have 3 narrow colpi with acute apices and lalongate $(95 \%)$ or circular $(5 \%)$ ora. Exine ornamentation is irregularly rugulate at the equator and rugulostriate at poles. The size of grains $(\mathrm{P}=29-36 \mu \mathrm{m})$ confirms data reported by De Leonardis et al. (1984b, 1988) for taxa of the same tribe (Peucedaneae), namely Ferula communis L., Opoponax chironium (L.) Koch, Tordylium apulum L. Grain size $(\mathrm{P}=50-57 \mu \mathrm{m})$ differs only in Heracleum pyrenaicum Lam. ssp. cordatum (Presl) Pedrotti et Pignatti due to the presence of columellar hypertrophy in the polar zone, (fig. 6: 3-4).

\section{Petagnia saniculifolia Guss.}

Hypertrophy does not occur. The polar outline is pleurotreme subtriangular with nonprotruding apices. Shape is subrectangular with 3 narrow longitudinal colpi equipped with acute apices. Ora are lalongate $(93 \%)$ and circular (7\%). Exine is rugulate. The size of grains is a distinct distinguishing character within the three taxa: $\mathrm{P}=22-28 \mu \mathrm{m}$ in Seseli bocconi ssp. bocconi, $\mathrm{P}=29-36 \mu \mathrm{m}$ in Bonannia graeca and $\mathrm{P}=48-56 \mu \mathrm{m}$ in $P$. saniculifolia, (fig. 6: 5-6).

\section{MATERIAL EXAMINED:}

Acinos granatensis (Boiss. ex Reuter) Pignatti ssp. aetnensis (Strobl) Pignatti: Piano ProvenzanaEtna (Catania), A. Zizza. (CAT 92052015).

Arabis rosea DC.: Fornazzo (Catania), W. De Leonardis \& A. Zizza. (CAT 92042205).

Astragalus nebrodensis (Guss.) Strobl: Piano della Battaglia-Madonie (Palermo), W. De Leonardis \& A. Zizza. (CAT 92062518). 


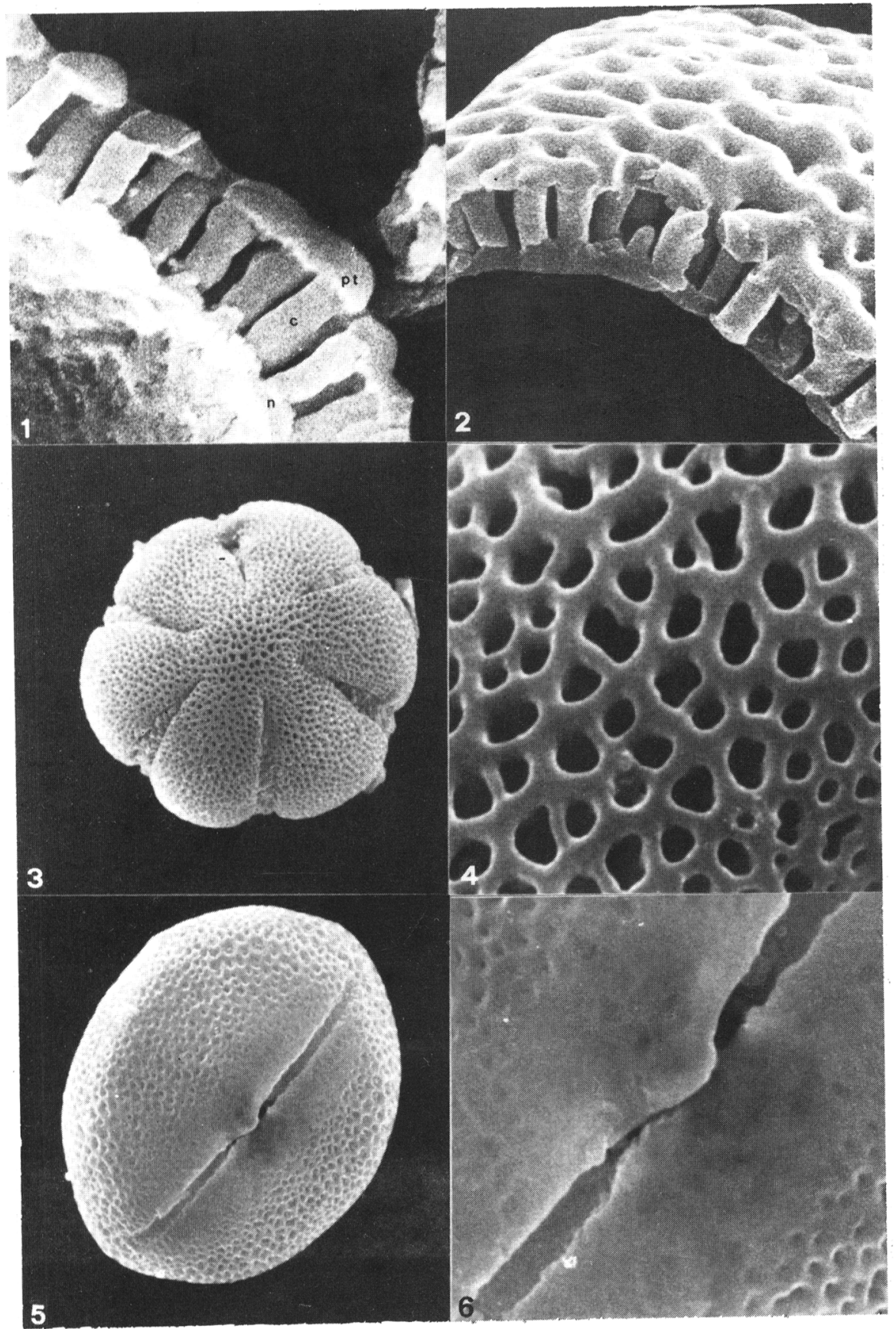

Figure 3: 1, Euphorbia gasparrinii ssp. gasparrinii: exine section with nexine (n), columellae (c) and partial tectum (pt) $(10,000 \mathrm{x}) .2$, E. corallioides, sexine with funnel-shaped cavities $(9,000 \mathrm{x})$. 3, Acinos granatensis ssp. aetnensis, polar view $(2,800 \mathrm{x})$. 4, A. granatensis ssp. aetnensis, reticulum $(10,000 \mathrm{x}) .5$, Astragalus nebrodensis, equatorial view (2,400x), 6, A. nebrodensis, colpus with margo (m) (10,000x). 


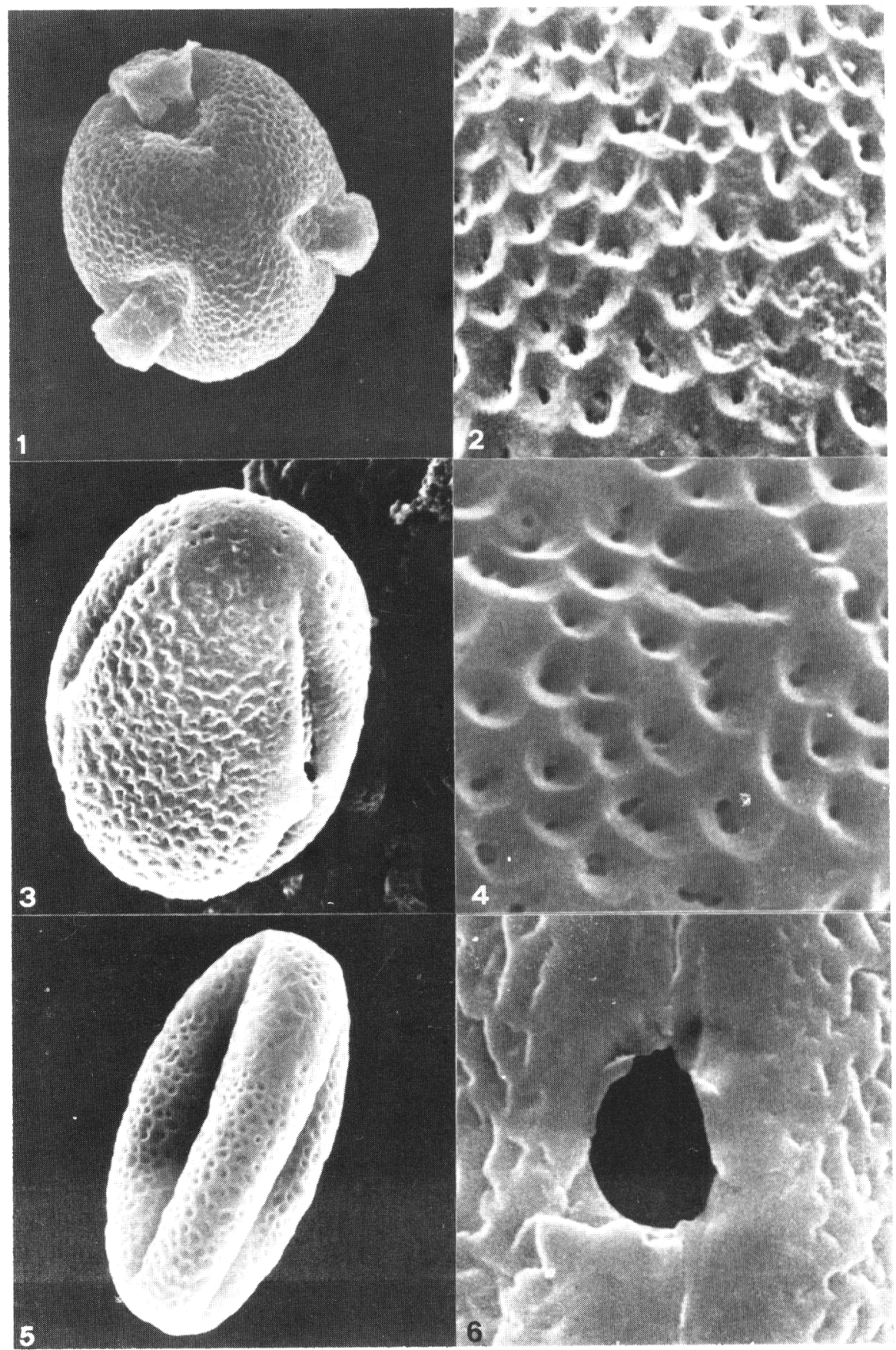

Figure 4: 1, Cytisus aeolicus: polar view $(2,400 x)$. 2, C. aeolicus, sexine with funnel-shaped cavities $(10,000 \mathrm{x}) .3$, Lathyrus odoratus, equatorial view $(3,200 \mathrm{x}) .4$, L. odoratus, sexine with funnel-shaped cavities $(10,000 \mathrm{x}) .5$, Retama raetam ssp. gussonei, equatorial view $(2,200 \mathrm{x}) .6$, R. raetam ssp. gussonei, colpus and os $(4,800 \mathrm{x})$. 

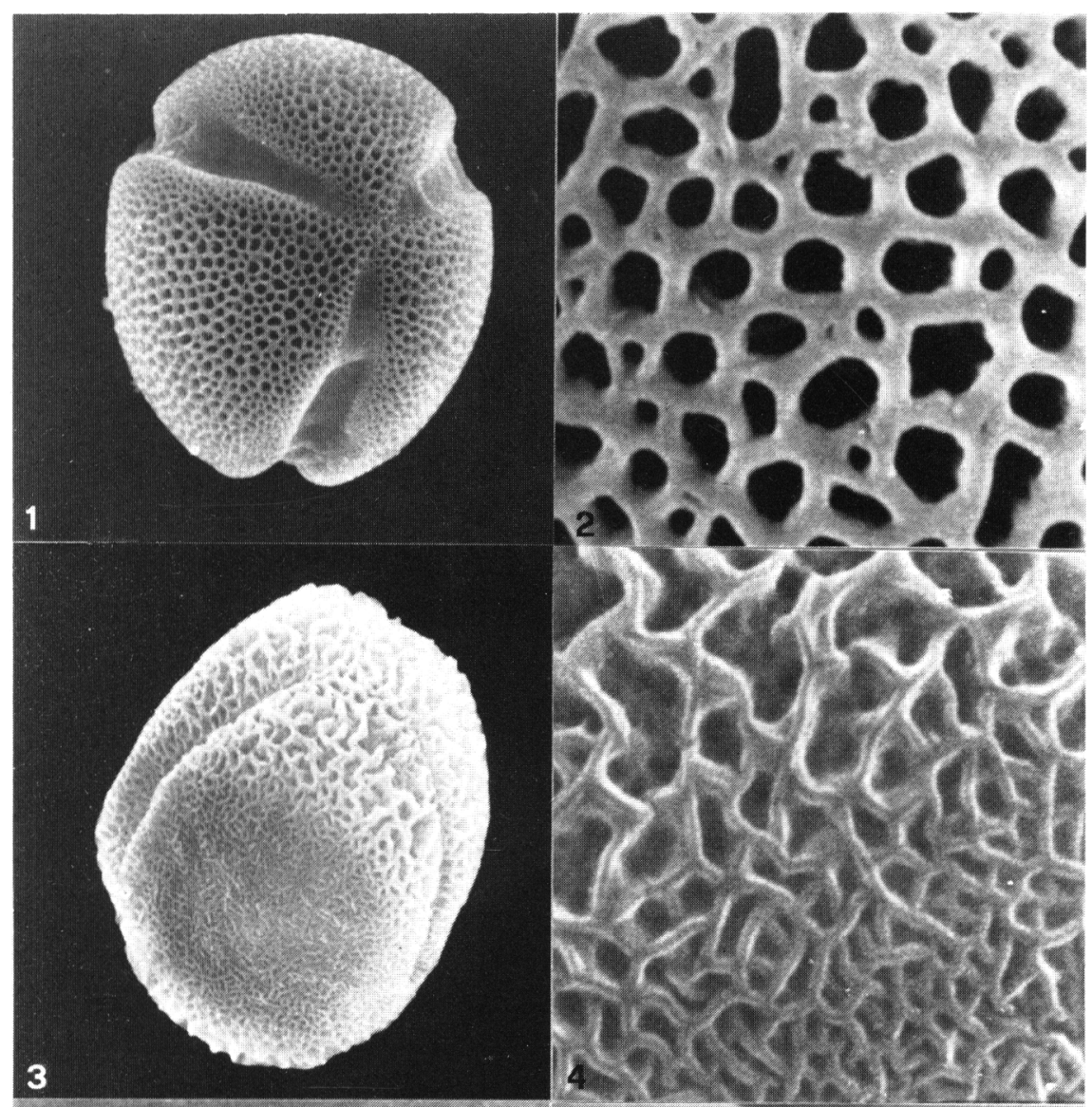

3
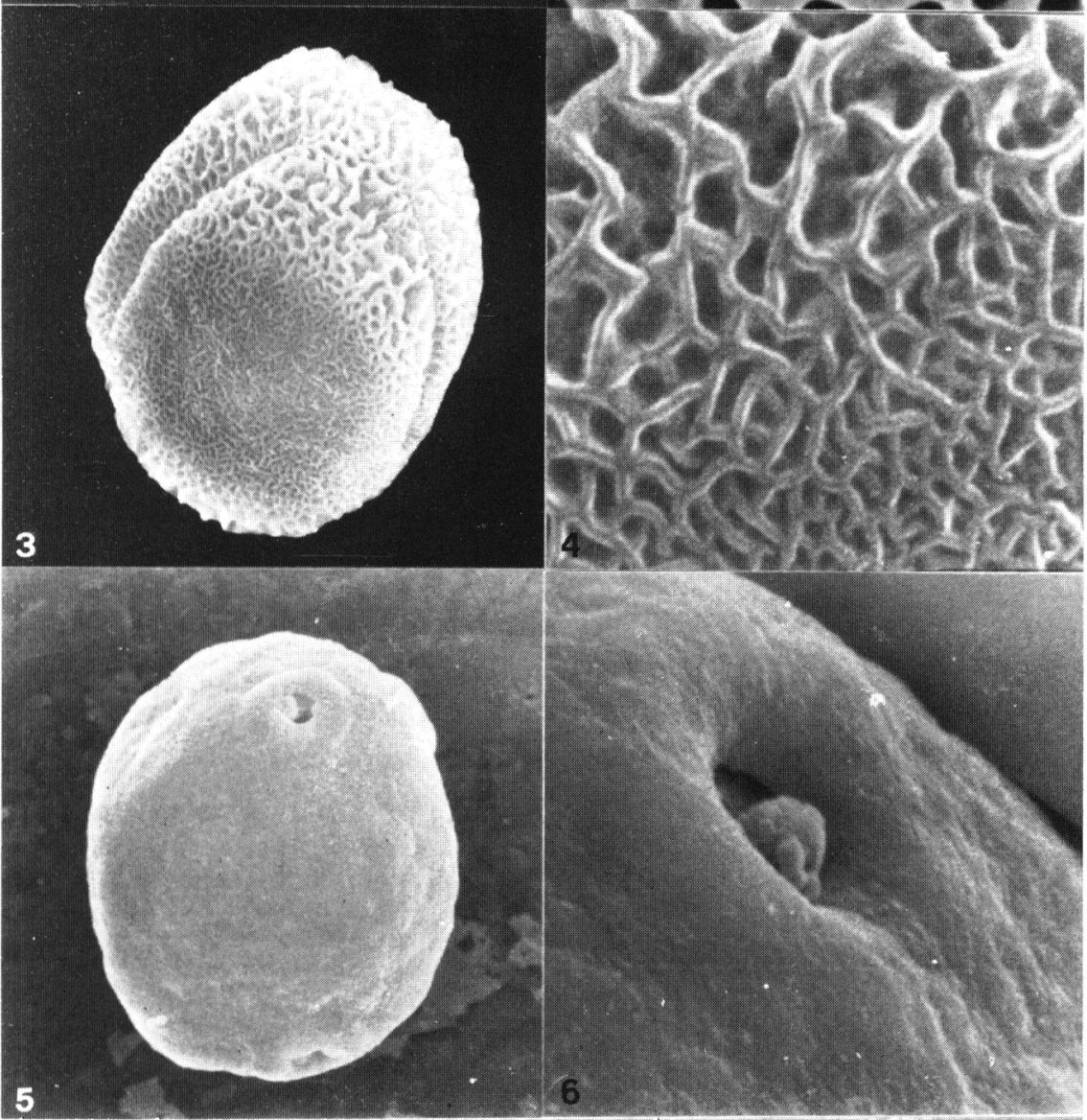

Figure 5: 1, Verbascum rotundifolium: polar view (2,600x). 2, V. rotundifolium, reticulum $(10,000 \mathrm{x}) .3$, Odontites bocconei, equatorial and polar views $(3,000 \mathrm{x}) .4,0$. bocconei, ornamentation with lumina from small to large $(10,000 x) .5$, Celtis aetnensis, apolar grain $(1,600 \mathrm{x}) .6$, C. aetnensis, porus with operculum and annulus $(7,200 x)$. 


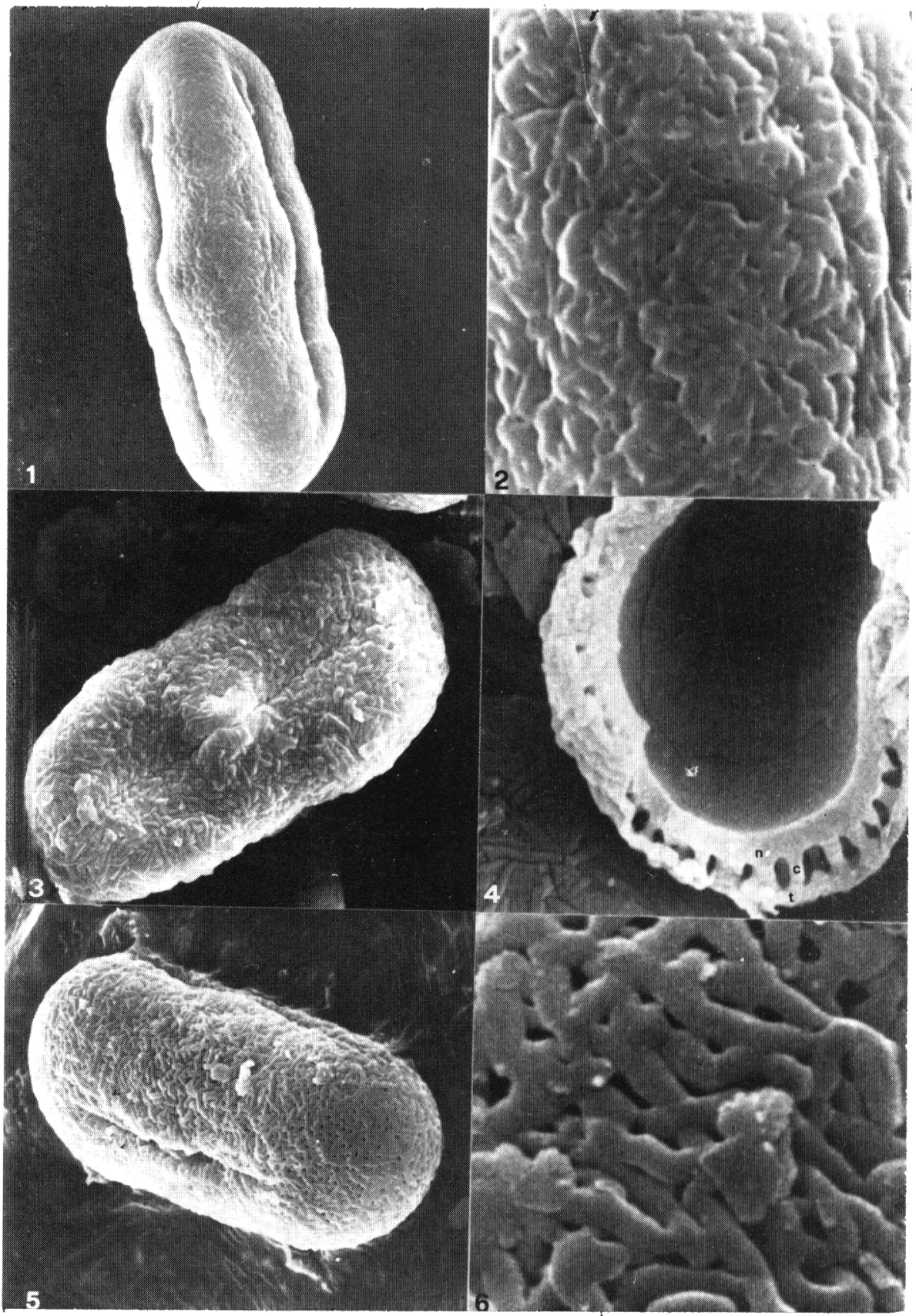

Figure 6: 1, Seseli bocconi ssp. bocconi: equatorial view with mesocolpium (3,000x). 2, S. bocconi ssp. bocconi, rugulate ornamentation $(10,000 \mathrm{x})$. 3, Bonannia graeca, equatorial view with colporate aperture $(3,000 \mathrm{x}) .4$, B. graeca, exine section with nexine (n), columellae (c) and tectum (t) $(5,400 \mathrm{x}) .5$, Petagnia saniculifolia, equatorial view with mesocolpium $(2,200 \mathrm{x}), 6, P$. saniculifolia, rugulae $(10,000 \mathrm{x})$. 


\begin{tabular}{|c|c|c|c|}
\hline Taxa & $\mathbf{P}$ & $\mathbf{E}$ & NPC \\
\hline \multicolumn{4}{|l|}{ Acinos granatensis } \\
\hline ssp. aetnensis & $24(28) 33$ & $26(32) 37$ & 643 \\
\hline Arabis rosea & $26(29) 32$ & $26(27) 29$ & 343 \\
\hline Astragalus nebrodensis & $25(27) 30$ & $20(21) 22$ & 345 \\
\hline Berberis aetnensis & $32(42) 50 *$ & $31(40) 48 * *$ & 803 \\
\hline Betula aetnensis & $17(22) 25$ & $26(27) 30$ & 344 \\
\hline Bonannia graeca & $30(33) 36$ & $14(15) 18$ & 345 \\
\hline \multirow[t]{2}{*}{ Celtis aetnensis } & $22(25) 30$ & $25(30) 31$ & $\begin{array}{l}344(34 \%) \\
444(44 \%)\end{array}$ \\
\hline & & & $764(20 \%)$ \\
\hline Cytisus aeolicus & $19(21) 23$ & $20(21) 22$ & 345 \\
\hline Erysimum metlesicsii & $17(18) 20$ & $18(19) 20$ & 343 \\
\hline \multicolumn{4}{|l|}{ Euphorbia amygdaloides } \\
\hline ssp. arbuscula & $32(34) 38$ & $34(36) 39$ & 345 \\
\hline E. ceratocarpa & $39(48) 54$ & $34(39) 43$ & 345 \\
\hline E. corallioides & $40(47) 53$ & $30(40) 48$ & 345 \\
\hline \multicolumn{4}{|l|}{ E. gasparrinii } \\
\hline ssp. gasparrinii & $36(42) 50$ & $33(36) 40$ & 345 \\
\hline Lathyrus odoratus & $46(49) 52$ & $29(32) 34$ & 345 \\
\hline \multicolumn{4}{|l|}{ Matthiola incana } \\
\hline ssp. rupestris & $22(23) 26$ & $22(23) 25$ & 343 \\
\hline M. fruticulosa & $22(24) 26$ & $22(23) 25$ & 343 \\
\hline Odontites bocconei & $19(22) 24$ & $9(24) 26$ & 343 \\
\hline \multicolumn{4}{|l|}{ Retama raetam } \\
\hline ssp. gussonei & $21(25) 30$ & $19(24) 30$ & 345 \\
\hline \multicolumn{4}{|l|}{ Seseli bocconi } \\
\hline ssp. bocconi & $23(27) 28$ & $14(15) 16$ & 345 \\
\hline Verbascum rotundifolium & $21(23) 25$ & $24(25) 27$ & 345 \\
\hline
\end{tabular}

Table 1 - Measurements expressed in $\mu \mathrm{m}$ in endemic taxa from Sicily and Central-Southern Italy. Abbreviations adopted for measurements: $\mathbf{P}=$ polar axis; $\mathbf{E}=$ equatorial axis; $\mathbf{D M}=$ longest diameter; $\mathbf{D m}=$ shortest diameter; NPC (sensu Erdtman 1969)= number, position, character of the apertures.* refered to DM; ** refered to $\mathbf{D m}$.

Betula aetnensis Rafin.: Rifugio Citelli-Etna (Catania), W. De Leonardis \& A. Zizza. (CAT 91043013).

Berberis aetnensis C. Presl: Piano Provenzana-Etna (Catania), W. De Leonardis \& A. Zizza. (CAT 92052014).

Bonannia graeca (L.) Halacsy: Mt. QuacellaMadonie (Palermo), W. De Leonardis \& A. Zizza. (CAT 92062523).

Celtis aetnensis Strobl: Bronte (Catania), W. De Leonardis \& A. Zizza. (CAT 92041915).

Cytisus aeolicus Guss.: O.B. Catania, (CAT 88032801).

Erucastrum virgatum (J.\& C. Presl) C. Presl:
Milazzo (Messina), W. De Leonardis \& A. Zizza. (CAT 92042205).

Erysimum metlesicsii Polatschek: O.B. Catania, (CAT 92050701).

Euphorbia amygdaloides L. ssp. arbuscula Meusel: Portella Miraglia-Nebrodi (Messina), W. De Leonardis \& A. Zizza. (CAT 92053022).

Euphorbia ceratocarpa Ten.: Maniace-Bronte (Catania), W. De Leonardis \& A. Zizza. (CAT 91050504).

Euphorbia corallioides L.: Portella Mandrazzi (Messina), W. De Leonardis \& A. Zizza. (CAT 91061051).

Euphorbia gasparrinii Boiss. ssp. gasparrinii: Mt. 
Soro-Nebrodi (Messina), W. De Leonardis \& A. Zizza. (CAT 91061532).

Lathyrus odoratus L.: Enna, W. De Leonardis \& A. Zizza. (CAT 91052116).

Matthiola fruticulosa (L.) Maire: Mt. Capodarso (Enna), W. De Leonardis \& A. Zizza. (CAT 92041008).

Matthiola incana (L.) R. Br. ssp. rupestris (Rafin.) Nyman: Salina (Isole Eolie), W. De Leonardis \& A. Zizza. (CAT 90053006).

Odontites bocconei (Guss.) Walpers: Mt. QuacellaMadonie (Palermo), W. De Leonardis \& A. Zizza. (CAT 92100817).

Petagnia saniculifolia Guss.: Tortorici (Messina), W. De Leonardis \& A. Zizza. (CAT 91041820).

Retama raetam (Forsskàl) Webb ssp. gussonei (Webb) Greuter: Gela (Caltanissetta), W. De Leonardis \& A. Zizza. (CAT 92031612).

Seseli bocconi Guss. ssp. bocconi: Capo Grosso (Palermo), W. De Leonardis \& A. Zizza. (CAT 91101506).

Verbascum rotundifolium Ten. ssp. rotundifolium: Petralia Soprana (Palermo), W. De Leonardis \& A. Zizza. (CAT 92062520).

\section{REFERENCES}

ACCORSI, C.A., M. BANDINI MAZZANTI, L. FORLANI \& M. ROSSITTO -1984Palynological Italian Flora. Species of Sicilian Flora: Cards Nos. 92-99. Webbia, 38: 545-576.

BIRKS, H.J.B. -1969- The identification of Betula nana pollen. New Phytol., 67: 309-314.

BONNEFILLE, R. -1971- Atlas des pollens d'Ethiopie. Principales espèces des forets de montagne. Pollen et Spores, 13(1): 15-72.

BOOTELLO, M.L., M.I. HIDALGO \& M.M. TRIGO -1989- Sobre la palinología de algunas especies endémicas e interesantes de Andalucía oriental.II. Acta Bot. Malacitana, 14: 245-253.

DE LEONARDIS, W., A. DURO, N. LONGHITANO, V. PICCIONE, C. SCALIA \& A. ZIZZA - 1984b-Schede melissopalinologiche della Flora Apistica Siciliana. II. Boll. Acc. Gioenia Sci. Nat., 17(324): 291-375.

DE LEONARDIS W., A. DURO, N. LONGHITANO, V. PICCIONE, C. SCALIA \& A. ZIZZA - 1988- Schede melissopalinologiche della Flora Apistica Siciliana. V. Boll. Acc. Gioenia Sci. Nat., 21(333): 75-167.

DE LEONARDIS W., A. DURO, V. PICCIONE \& M. ROSSITTO - 1984a- Flora Palinologica Ita- liana. Palinoschede di specie endemiche e subendemiche siciliane. Boll. Acc. Gioenia Sci. Nat., 17(324): 495-528.

DE LEONARDIS W., N. LONGHITANO, R. MELI, V. PICCIONE \& A. ZIZZA -1982- Schede melissopalinologiche della Flora Apistica Siciliana $I^{\circ}$. Inform. Bot. Ital., 14(1): 27-93.

DE LEONARDIS W., R. PALMIERI MATARESE, M. ROSSITTO \& A. ZIZZA -1986aMorfobiometria pollinica all'O.M., al S.E.M., al T.E.M. di specie endemiche siciliane. Boll. Acc. Gioenia Sci.Nat., 19(328): 143-167.

DE LEONARDIS,W., R. PALMIERI MATARESE, M. ROSSITTO \& A. ZIZZA - 1989a- Contributo alla conoscenza di taxa endemici della Sicilia attraverso l'analisi morfobiometrica del polline. Acta Bot. Malacitana, 14: 117-128.

DE LEONARDIS, W., V. PICCIONE, A. ZIZZA \& M. SANTORO -1986b- Flora Palinologica Italiana: Atlante-Glossario. Boll. Acc. Gioenia Sci. Nat., 19(329): 5-82.

DÍEZ, M.J.-1987- Ulmaceae. In: B.VALDÉS, M.J. DÍEZ \& I. FERNÁNDEZ (eds.). Atlas polínico de Andalucía Occidental, Sevilla

ERDTMAN, G. -1960- The acetolysis method. Svensk. Bot. Tidskr., 54: 561-564.

ERDTMAN, G. -1969- Handbook of Palynology. Munksgaard.

FAEGRI, K. \& J. IVERSEN -1975- Textbook of modern pollen analysis. Copenhagen.

FERNÁNDEZ, I. -1987a- Berberidaceae. In: B.VALDÉS, M.J. DÍEZ \& I. FERNÁNDEZ (eds.). Atlas polínico de Andalucía Occidental, Sevilla

FERNÁNDEZ, I. - 1987b- Fabaceae. In: B.VALDÉS, M.J. DÍEZ \& I. FERNÁNDEZ (eds.). Atlas polínico de Andalucía Occidental, Sevilla

FERGUSON, I.K. \& R. STRACHAN -1982- Pollen morphology and taxonomy of the tribe Indigofereae (Leguminosae: Papilionoideae). Pollen et Spores, 25: 171-210.

GODOY, M.C. \& M.J. DÍEZ -1987Scrophulariaceae. In: B. VALDÉS, M.J. DÍEZ \& I. FERNÁNDEZ (eds.). Atlas polínico de Andalucía Occidental, Sevilla

INCEOGLU, O. -1982- Pollen grains in some Turkish Rhinantheae (Scrophulariaceae). Grana, 21: 83-96.

LIEUX, M.H. -1980- An atlas of pollen of trees, shrubs and woody vines of Louisiana and other 
southeastern states, part II. Platanaceae to Betulaceae. Pollen et Spores, 22(2): 191-243.

LUQUE, T. \& P. CANDAU -1987- Lamiaceae (Labiatae). In: B.VALDES, M.J. DIEZ \& I. FERNÁNDEZ (eds.). Atlas polínico de Andalucía Occidental, Sevilla

MOORE, P.D. \& J.A. WEBB -1978- An illustrated guide to pollen analysis. Hodder and Stoughton, London.

NILSSON, S., J. PRAGLOWSKI \& L. NILSSON 1977-Atlas of airborne pollen grains and spores in Northern Europe. Natur och Kutur. Ljunforetagen. Orebro, Stockholm.

NOWICKE, J.W. \& J.J. SKVARLA -1981- Pollen morphology and phylogenetic relationships of the Berberidaceae s.l. Smithson. Contrib. Bot., 50: $1-83$.

PARDO, C. - 1982- Morfología polínica del género Seseli L. (Apiaceae) en la Península Ibérica. Lazaroa, 4: 207-255.

PUNT, W. -1984- Umbelliferae. In: W. Punt \& G.C.S. Clarke (eds.). The Northwest European pollen flora. Elsevier, Amsterdam, 4: 155-363.
TAKEOKA, M. \& E. STIX -1963- On the fine structure of the pollen walls in some Scandinavian Betulaceae. Grana Palynol., 4(2): 161-188.

TRIGO, M.M., M.I. HIDALGO, M.L. BOOTELLO \& B. CABEZUDO -1991- Sobre la palinología de algunas especies endémicas e interesantes de Andalucía oriental. IV. Acta Bot. Malacitana, 16(2): 500-508.

WODEHOUSE, R.P. -1932- Tertiary pollen. I. Pollen of the living representatives of the Green River flora. Bull. Torrey Bot. Cl. 59.

Aceptado para su publicación en Junio de 1994

Author's address. Department of Botany, University of Catania, Italy 